\title{
Optimization of a Process for a Microgreen and Fruit Based Ready to Serve Beverage
}

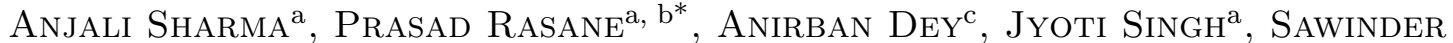 \\ KaUR $^{\mathrm{a}}$, Kajal Dhawan ${ }^{\mathrm{a}}$, Ashwani Kumar ${ }^{\mathrm{a}}$, AND Hari Shankar Joshi ${ }^{\mathrm{d}}$ \\ a Department of Food Technology and Nutrition, Lovely Professional University, Jalandhar Punjab-144411 \\ ${ }^{\mathrm{b}}$ Centre of Food Science and Technology, Banaras Hindu University, Varanasi 221005, India \\ ${ }^{c}$ Pimpernel Food Products Pvt. Ltd. Hooghly, West Bengal 712136, India \\ ${ }^{\mathrm{d}}$ College of Applied Food and Dairy Technology, Minbhawan, New Baneshwor, Kathmandu, Nepal, G.P.O. \\ Box: 11898 \\ ${ }^{*}$ Corresponding author \\ rasaneprasad@gmail.com \\ TEL: +918968976119
}

Received: 6 August 2018; Published online: 24 February 2021

\begin{abstract}
A process for preparation of a microgreen and fruit based beverage was optimized using spinach (Spinacia oleracea) microgreen, pomegranate (Punicagranatum), pineapple (Ananascomosus) and sugar. The blended juice in different ratios was analysed for total soluble solids, viscosity, sedimentation, acidity, metal chelation activity, free radical scavenging activity and reducing power. The optimized beverage had $17.26 \mathrm{~mL} 100 \mathrm{~mL}^{-1}$ spinach microgreen juice, $57.07 \mathrm{~mL} 100 \mathrm{~mL}^{-1}$ pomegranate

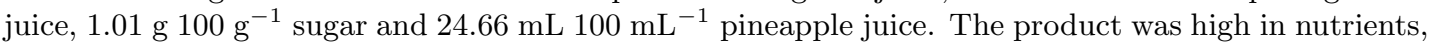
particularly protein, minerals (sodium, potassium and iron) and vitamins (vitamin $\mathrm{C}$ ), and bioactive compounds (total phenols and total carotenoids), and had high antioxidant activity (metal chelation activity, free radical scavenging activity and reducing power). The antioxidants and bioactive compounds present in juice were designed to help reduce oxidative stress during inflammatory cases such as arthritis.
\end{abstract}

Keywords: Antioxidants; Microgreen blend; Response Surface Methodology; Physicochemical properties

\section{Introduction}

Microgreens are young and tender edible greens produced from different species of vegetables, aromatic herbs and herbaceous plants. Microgreens are usually harvested after 7-14 days of germination when they grow to $2.5-7.6 \mathrm{~cm}$ (1-3 inch) in height and the cotyledonary leaves are fully developed with a small pair of true leaves (Di Gioia, Bellis, Mininni, Santamaria \& Serio, 2017; Kou et al., 2013; Xiao, Lester, Luo \& Wang, 2012). They are increasingly used by chefs

Copyright (C)2021 ISEKI-Food Association (IFA) as edible garnishing and to provide vivid colour, intense flavour and tender texture to food such as salads, soups and sandwiches (Di Gioia et al., 2017). Microgreens are considered as highly perishable products because they are very delicate and have short shelf life i.e. 1-2 days at ambient temperature. Microgreens are highly rich in bioactive compounds, vitamins, minerals, antioxidants and phytonutrients such as $\alpha$-tocopherol and $\beta$-carotene as compared to mature leaves (Kou et al., 2013; Xiao et al., 2014). Due to their high nutritive value, health promoting and 
disease preventing properties thay are considered as a "functional food". Over the last few years, they have begun to appear in farmer's market, upscale markets and restaurants as the demand for microgreens increases. Therefore, it is becoming important to study their utility in various commercial preparations that could improve their shelf life and delivery of their valuable nutrients to the consumers (Mir, Shah \& Mir, 2017; Xiao et al., 2014).

Spinaciaoleraceais belongs to Amaranthaceae family and is commonly known as spinach (Mehta \& Belemkar, 2014). It is considered as a "poor man's vegetable" because of its low production cost and high yield (Yadav, Kalia, Kumar \& Jain, 2013). It is one of the most nutritious leafy vegetable, ranking second behind kale in total folate and carotenoid content. In India, the plant is known as palak and has long been used as a diuretic, laxative and anti-inflammatory agent. Spinach microgreen is harvested 7-14 days after germination and 1-3 inches in height. They are sown at closer density than regular spinach and thus the leaves are smaller and hence the name (Bergquist, 2006). The spinach microgreen is a rich source of carotenoids (such as lutein, violaxanthin, zeaxanthin and $\beta$-carotene), phenolic compounds (para-coumaric acid, ferulic acid, ortho-coumaric acid) and flavonoids which act as powerful antioxidants to fight against free radical damage and protect the body from many diseases (Mehta \& Belemkar, 2014; Rao, Tabassum, Babu, Raja \& Banji, 2015). Quercetin is a bioflavonoid present in spinach which exhibits antioxidant, anti-proliferative, anti-inflammatory and hepatoprotective properties. Spinach is also associated with easing pain of arthritis due to its anti-inflammatory property (Gaikwad, Shete \& Otari, 2010). Other vegetarian sources like fruits, particularly pineapple contains nutrients such as carbohydrates, vitamin $\mathrm{C}, \beta$-carotene, protein, fat, ash and fibre, and bioactive compounds such as flavonoids and phenols which acts as antioxidant, anti-carcinogenic, antimicrobial, anti-mutagenic and anti-inflammatory agents (da Silva, Nogueira, Duzzioni \& Barrozo, 2013; Goh, Mohd Adzahan, Leong, Sew \& Sobhi, 2012). Pineapple contains bromelain, a proteolytic enzyme which digests the proteins in the food. It is popular amongst athletes for the treatment of injuries and other physical aches (Debnath, Dey, Chanda \& Bhakta, 2012). It also has an antiinflammatory effect on soft tissue injury and reduces swelling and pain (Kumar, Chandra, Kumar \& Prince, 2016). Pomegranate is obtained from arils which are rich sources of bioactive compounds with abilities to reduce inflammation and fight the enzyme that destroys the cartilage (Anahita, Asmah \& Fauziah, 2015; Bhowmik, Gopinath, Kumar \& Kumar, 2013). The combination of fruits makes a healthy diet to provide all the basic nutrients that are present in different juices (Akusu, Kiin-Kabari \& Ebere, 2016; Landon, 2007). The consumption of fruit juice may be influenced by sensory quality and nutritive value. Recently herbal formulations have been given due attention owing to their therapeutic potential (Clark, 1995).

The present work focuses on optimizing a process for preparation of a microgreen and fruit based beverage with acceptable sensory and physicochemical properties. Spinach microgreen was blended with fruits such as pomegranate and pineapple to increase its acceptability and nutrient potential.

\section{Materials and Methods}

\subsection{Cultivation of microgreens}

The spinach (Spinaciaoleraceais) microgreens were cultivated in the experimental farm under low pressure controlled polyhouse conditions in Lovely Professional University, Punjab, India. Indirect and low air circulation was provided. The temperature was regulated between 18 and $26{ }^{\circ} \mathrm{C}$ and the relative humidity was controlled to 50\%. Pineapple (Queen Variety) and pomegranate (Mridula Variety) were purchased from the farmers' market of Jalandhar, India. 


\subsection{Optimization by response surface methodology (RSM)}

The product was optimized using response surface methodology (RSM). Product variables included spinach microgreen juice (10-20 mL $\left.100 \mathrm{~mL}^{-1}\right)$, pomegranate juice $(40-60 \mathrm{~mL} 100$ $\left.\mathrm{mL}^{-1}\right)$, sugar (0-2 g $\left.100 \mathrm{~g}^{-1}\right)$ and pineapple juice which were added to make up a total formulation of $100 \mathrm{~mL}$ in required experiments. Twenty trials were carried out to optimize the microgreen based functional juice.

\subsection{Proximate composition}

\section{Moisture content}

The moisture content was determined by AOAC (2000) method. The sample (5 g) was weighed accurately and then weighed again in a petri plate. It was then heated at $110 \pm 2{ }^{\circ} \mathrm{C}$ for $4 \mathrm{~h}$ in a hot air oven. The plate was removed. This was followed by cooling in a desiccator and weighed at one hour intervals until constant weight was attained. The moisture content was determined by the following equation:

$$
\text { Moisture content }(\%)=W_{2}-\frac{W_{1}}{W} \times 100
$$

Where $\mathrm{W}_{1}$ and $\mathrm{W}_{2}=$ weight of petri plate along with sample before and after drying respectively and $\mathrm{W}=$ weight of sample.

\section{Ash content}

The ash content was determined by the method of Romelle, Rani and Manohar (2016). The sample (2 g) was taken in a silica dish and ignited over a low flame to char the organic matter. After complete charring, the dish was placed in a muffle furnace and heated at $550{ }^{\circ} \mathrm{C}$ for $3-4 \mathrm{~h}$, till greyish to off white ash was obtained. The dish containing ash was cooled in a desiccator and weighted. The percentage ash was calculated as follows:

$$
\text { Ash content }(\%)=\frac{\text { wt. of ash }}{\text { wt. of sample }} \times 100
$$

\section{Protein content}

The protein content was analysed by the Kjeldhal method suggested by Rangana (1997). A weighed sample $(0.5 \mathrm{~g})$ was digested along with concentrated sulphuric acid $(20 \mathrm{~mL})$ and $5 \mathrm{~g}$ digestion mixture (10 $\mathrm{g}$ potassium sulphate and 1 g copper sulphate) in a Kjeldhal digestion flask. The contents were cooled, diluted with a small amount of distilled water and transferred into a $50 \mathrm{~mL}$ volumetric flask. The volume was made up to the mark with addition of distilled water. A measured aliquot $(5 \mathrm{~mL})$ was taken in a distillation flask followed by $10 \mathrm{~mL}$ of $40 \% \mathrm{NaOH}$. Ammonia liberated was collected through a condenser in a flask containing $10 \mathrm{~mL}$ of $0.1 \mathrm{~N} \mathrm{HCl}$, prior to which methyl red indicator was added. The methyl red indicator solution containing liberated $\mathrm{NH}_{3}$ was titrated against $0.1 \mathrm{~N} \mathrm{NaOH}$. The amount of $\mathrm{NaOH}$ used to neutralize the indicator was recorded. One blank containing concentrated sulphuric acid and digestion mixture was also run along with the experimental samples.

By this method, the percentage of nitrogen present in the sample was calculated and then the crude protein content was calculated as follows:

$$
\begin{gathered}
N(\%)=\frac{[A-B] \times 0.0014 \times \text { vol. of digest }}{\text { Aliquot taken } \times S} \times 100 \\
\text { Protein }(\%)=N(\%) \times 6.25
\end{gathered}
$$

Where $\mathrm{A}=$ Sample titre $(\mathrm{mL}), \mathrm{B}=$ Blank titre $(\mathrm{mL}), \mathrm{S}=$ Weight of sample taken

\section{Fat content}

The Fat content was determined by the Soxhlet extraction method (AOAC, 2000). Dried samples (2 g) were extracted with Petroleum ether $(100 \%)$ in the Soxhlet extraction apparatus for $6-8 \mathrm{~h}$ in a pre-weighed round bottom flask. The extract containing fat and petroleum ether was evaporated over a boiling water bath and dried in an oven at low temperature and weighed. The differences in the weight of the round bottom flask represented the ether extract (fat content) present in the sample and were calculated as:

$$
\text { Fat content }(\%)=\left(W_{1}-\frac{W_{2}}{W}\right) \times 100
$$


SI44 | Sharma et al.

Where, W (g) = Weight of sample, W1 (g) = Weight of empty round bottom flask, $\mathrm{W}_{2}(\mathrm{~g})=$ Weight of empty round bottom flask + Fat content

\section{Titratable Acidity}

Titratable acidity was estimated by the method according to Lugwisha (2014). A known volume of sample was titrated against $0.1 \mathrm{~N} \mathrm{NaOH}$ standard solutions by using phenolphthalein as an indicator up to the end point (Pink color). The titratable acidity was calculated as:

$$
T A=\frac{T_{w} \times N A \times V o l_{m} \times A_{e q} \times 100}{V_{s} \times V_{a l} \times 1000}
$$

Where $T A$ is the Titratable acidity $(\%), T_{w}$ is the Titre weight, $N A$ is the Normality of alkali, $V_{o l} l_{m}$ is the Vol. make up, $A_{e q}$ is the Equivalent of acid, $V_{s}$ is the Volume of sample taken and $V_{a l}$ is the Volume of aliquot taken.

\section{Minerals and Vitamin (Ascorbic acid)}

Sodium and potassium contents were determined by the flamephotometery process suggested by Rangana (1997). Iron content of the microgreen blend was estimated by using the method of Achikanu, Eze-Steven, Ude and Ugwuokolie (2013). The sample solution $(2.5 \mathrm{~mL})$ was pipetted in $0.4 \mathrm{~mL}$ of $\mathrm{NaOH}(5 \mathrm{M})$ to maintain the $\mathrm{pH}$ between 4.0-4.5. Acetate buffer $(0.7 \mathrm{~mL}, \mathrm{pH} 4.5)$ was added along with $0.5 \mathrm{~mL}$ of Hydroquinone (25\%). $\alpha^{1} \alpha^{1}$ Dipridyl $0.1 \%$ of $0.5 \mathrm{~mL}$ was added. Distilled water $(0.35 \mathrm{~mL})$ was used to make the volume up to $5 \mathrm{~mL}$. The absorbance was taken against a blank at $520 \mathrm{~nm}$. Ascorbic acid content was measured by using dye, 2,6-dichlorophenolindophenol titration method according to Rekha et al. (2012).

\section{Total soluble solids (TSS)}

TSS was determined using a hand-held refractometer of range $0-30{ }^{\circ}$ Brix. The TSS was recorded by placing 1-2 drops of juice sample on the prism of the hand-held refractometer. The results were expressed as ${ }^{\circ}$ Brix (Fawole \& Opara, 2013).

\subsection{Antioxidant properties}

\section{Reducing power}

The microgreen juice blend was evaluated for reducing power using the Ferricyanide-ferric chloride method. Microgreen based juice blend ( 0.5 $\mathrm{mL}$ ) was added to test tubes along with $2.5 \mathrm{~mL}$ potassium phosphate buffer $(0.2 \mathrm{M}, \mathrm{pH} 6.6)$ and freshly prepared $1 \%$ potassium ferricyanide (2.5 $\mathrm{mL}$ ). The mixture was incubated in a water bath at $50{ }^{\circ} \mathrm{C}$ for 20 minutes. After adding $2.5 \mathrm{~mL}$ of $10 \%$ trichloroacetic acid to the mixture, it was then subject to centrifugation at $5000 \mathrm{rpm}$ for 5 minutes. The upper layer of the mixture (2.5 $\mathrm{mL}$ ) was taken and mixed with $2.5 \mathrm{~mL}$ of distilled water. Freshly prepared $0.1 \% \mathrm{FeCl}_{3}(0.5$ $\mathrm{mL}$ ) was added and the absorbance was measured at $700 \mathrm{~nm}$ against a blank Shiban, Al-Otaibi and Al-Zoreky (2012).

\section{FRSA (Free radical scavenging activity)}

FRSA (Free radical scavenging activity) was assessed using the 2,2-diphenyl-1-picrylhydrazyl method, with certain modifications. The microgreen based juice blend $(0.1 \mathrm{~mL})$ was dissolved with $2.9 \mathrm{~mL}$ of DPPH solution. The mixture was shaken vigorously and left to stand in the dark at room temperature for 30 minutes. The amount of FRSA was determined specrtophotometrically at $517 \mathrm{~nm}$ (Jenitha \& Anusuya, 2016) The free radical scavenging activity was calculated as \% inhibition from the following equation:

$$
\operatorname{FRSA}(\% \text { Inhibition })=\left(\text { OD control }-\frac{\text { OD sample }}{\text { OD control }}\right) \times 100
$$

OD - Optical density (Absorbance)

\section{Metal chelating activity}

FeSO4 solution $(0.25 \mathrm{~mL})$ and $0.5 \mathrm{~mL}$ of sample was taken in a test tube. Tris-HCL buffer $(1 \mathrm{~mL}$, $\mathrm{pH}$ 7.4) and 2,2 -bipyridyl solution was taken along with $2.5 \mathrm{~mL}$ of ethanol and made up the volume up to $5 \mathrm{~mL}$ with distilled water. The mixture was incubated at room temperature for 10 minutes and the absorbance was taken at $522 \mathrm{~nm}$ 
against a blank (Mohan, Balamurugan, Elayaraja \& Prabakaran, 2012). The metal chelation activity scavenging effect $\left(M_{\text {chel }}\right)$ was calculated by the following formula:

$$
M_{\text {chel }}=\left[\frac{\left(A_{0}-A_{1}\right)}{A_{0}} \times 100\right]
$$

Where $\mathrm{A}_{0}=$ absorbance of control, $\mathrm{A}_{1}=$ absorbance of sample

\section{Total Phenolic Content (TPC)}

Total phenolic content was determined spectrophotometrically at $765 \mathrm{~nm}$ by using folin- ciocalteu's reagent (Kamtekar, Keer \& Patil, 2014). Juice extract was mixed with $0.2 \mathrm{~mL}$ of folinciocalteu's reagent and the volume made up to $3 \mathrm{~mL}$ with distilled water. The mixture was incubated for 30 minutes at room temperature. 1 $\mathrm{mL}$ of $20 \%$ Sodium carbonate was added and the mixture boiled for 1 minute in a boiling bath and the absorbance was measured at $765 \mathrm{~nm}$ by using a UV-Vis spectrophotometer.

\section{Total carotenoid content}

Total carotenoid content of the microgreen based juice blend was determined spectrophotometrically. The sample $(3 \mathrm{~mL})$ was mixed with $10 \mathrm{~mL}$ of distilled water. Cold acetone $(20 \mathrm{~mL})$ was added and it was allowed to stand for 15 minutes. The filtered extract $(1 / 3)$ was mixed with petroleum ether $(20 \mathrm{~mL})$. Distilled water was added for the separation phase. The total carotenoid was determined at $450 \mathrm{~nm}$ wavelength using a UV-Vis spectrophotometer (Ding \& Syazwani, 2016).

\subsection{Viscosity (Ostwald viscometer)}

Viscosity of the microgreen based functional juice was measured using an Ostwald viscometer (Borosil, BT1UR3502007, India). The liquid was added to the viscometer, pulled into the upper reservoir by suction, and then allowed to drain by gravity into the lower reservoir, based on the time of flow through a volumetric capillary. The viscosity of different concentrations of juice was determined by using the following equation:

$$
\eta_{1}=\frac{\rho_{1} t_{1}}{\rho_{2} t_{2}} \times \eta_{2}
$$

Where, $\rho_{1}=$ density of unknown liquid, $\rho_{2}=$ density of liquids (water), $t_{1}=$ time of other liquids, $t_{2}=$ time of known liquid, $\eta_{2}=$ viscosity of known liquid.

\subsection{Sensory evaluation}

The microgreen based functional juice formulations were subjected to sensory evaluation using a 10-point hedonic scale which comprises colour and appearance, aroma, taste, mouthfeel, consistency and overall acceptability. The sensory evaluation was performed by a panel of 50 semitrained judges (25 males and 25 females; age: 20 40 years) from the campus of Lovely Professional University, Punjab (India).

\section{Results and Discussion}

\subsection{Nutritional composition and antioxidant activity of mature spinach and spinach microgreen}

The nutritional composition of spinach microgreen and mature spinach are compared in Table 1. There is a significant difference $(\mathrm{p}<0.05)$ between them in the amount of nutrients such as protein, minerals and vitamin C. Moreover, the antioxidant activity in the form of reducing power, metal chelation and free radical scavenging activity was found to be significantly $(\mathrm{p}<0.05)$ higher in the spinach microgreen as compared to their mature counterpart. It was reported by Janovská, Stocková and Stehno (2010); Xiao et al. (2012); Sun et al. (2013) and Weber (2017) that microgreens have high levels of vitamins and bioactive compounds and are dense sources of mineral nutrition as compared to mature plants. Pinto, Almeida, Aguiar and Ferreira (2015) showed that microgreens have a higher content of minerals and lower nitrate content than the mature leaves, and thus makes them an excellent source of minerals whilst reducing exposure to harmful nitrates. Microgreens

\begin{tabular}{l|l|l|l} 
IJFS & February 2021 & Volume 10 & pages SI41-SI56
\end{tabular} 
are a good source of both the microelements and macroelements with no traces of toxic elements as shown by Xiao et al. (2016).

\subsection{Optimization of process for microgreen and fruit based beverage}

The experimental setup for optimization and values for sensory and physico-chemical parameters for the experiment are as shown in the Tables 2 and 3 , respectively.

\subsection{Effects of juice blends on sensory properties of the beverage}

Table 4 shows the coefficient estimates for the sensory properties as a response. As evidenced from the Table, pomegranate had a significant $(\mathrm{p}<0.01)$ positive effect on colour and appearance, aroma, taste, consistency, mouthfeel and overall acceptability scores, while spinach negatively $(\mathrm{p}<0.01)$ affected the sensory properties except consistency. As the amount of pomegranate juice in the blend increased the overall acceptability of the juice blend also increased, owing to the bright red colour it imparts and also provides good mouthfeel. Lawless, Threlfall, Howard and Meullenet (2012) and Mohideen et al. (2015) showed that red colour is due to the anthocyanins and it positively affects consumer acceptance. However, sp inach provides a dark brown colour and gives a bitter mouthfeel. It was observed by Lawless et al. (2012) that the reaction of anthocyanins and tannins forms brown coloured complexes and thus imparts dark colour to the juice and a slight sour taste (Pimentel, Madrona \& Prudencio, 2015) decreasing consumer acceptance. Consistency of the blend was also positively affected by the amount of spinach and pomegranate juice. On the other hand, sugar had no significant effect on colour, appearance and aroma, while it positively affected the taste, consistency, mouthfeel and overall acceptability of the product (Fig. 1A). It was stated by Wisal, Ullah, Zeb and Khan (2013) that addition of sugar increases the consistency of juice samples and also sugar is an essential factor for the flavour. Sugar provides sweetness which is the most significant attribute for the acceptance of juice (Endrizzi, Gasperi, Rodbotten \& Naes, 2014).

\subsection{Effect of juice blend on physicochemical properties of the beverage}

\section{Total soluble solids}

As evident from Table 5, spinach and pomegranate had significant $(\mathrm{p}<0.01)$ positive effects on TSS. This might be due to the high sugar content present in pomegranate. Added sugar also had a significant effect on TSS but was less as the quantity of added sugar was lower. Fawole and Opara (2013) reported that TSS depends on the maturity of fruit. As the fruit is going towards maturity, starch is converted into sugars by hydrolysis and this enhances the sweetness and flavour. It was shown by Reboucas, Rodrigues, de Freitas and Ferreira (2016) that as the concentration of juice and sugar increases, the TSS of the juice blend also increases. The increase in TSS may also be due to the conversion of polysaccharides into oligosaccharides and monosaccharides as stated by Wisal et al. (2013), Oyeleke (2013) and Jan and Dorcus Masih (2012). It was also recorded by Lawless et al. (2012) that the increase in TSS increases the overall acceptance of the product.

\section{Viscosity}

Pomegranate and sugar also had an interactive significant $(\mathrm{p}<0.01)$ positive effect on the viscosity of the juice blend (Fig. 1B). This might be due to the presence of a greater amount of pulp. It is reported by Kar and Kaya (2014) that as the concentration of juice increases, the viscosity also increases. Pomegranate and spinach had a significant $(p<0.01)$ positive effect on sedimentation. As the concentration of pineapple and spinach increases the sedimentation increases (Table 3). It was claimed by Abedi, Sani and Karazhiyan (2014) that viscosity and sedimentation increases with an increase in pec- 
Table 1: Nutritional composition of mature spinach and spinach microgreen

\begin{tabular}{|c|c|c|}
\hline Nutrients & Spinach Mature & Spinach Microgreen \\
\hline Protein (\%) & $1.19 \pm 0.11^{b}$ & $2.45 \pm 0.06^{a}$ \\
\hline Moisture (\%) & $90.04 \pm 0.11^{b}$ & $94.2 \pm 0.20^{a}$ \\
\hline $\operatorname{Ash}(\%)$ & $1.05 \pm 0.04^{b}$ & $1.23 \pm 0.03^{a}$ \\
\hline Potassium (mg) & $132.0 \pm 0.04^{b}$ & $161.0 \pm 0.03^{a}$ \\
\hline Sodium $(\mathrm{mg})$ & $70.02 \pm 0.09^{b}$ & $78.02 \pm 0.03^{a}$ \\
\hline Total phenols $\left(\mathrm{GAE} \mathrm{g}^{-1}\right)$ & $0.59 \pm 0.08^{b}$ & $0.95 \pm 0.06^{a}$ \\
\hline Total carotenoids $\left(\mu \mathrm{g} 100 \mathrm{~g}^{-1}\right)$ & $10.80 \pm 0.05^{b}$ & $15.08 \pm 0.05^{a}$ \\
\hline Vitamin C (mg) & $9.06 \pm 0.28^{b}$ & $11.8 \pm 0.008 \mathrm{a}$ \\
\hline Reducing Power (\%) & $39.16 \pm 0.45^{b}$ & $48.86 \pm 0.15 \mathrm{a}$ \\
\hline Metal chelation activity (\% inhibition) & $33.41 \pm 0.05^{b}$ & $39.59 \pm 0.36^{a}$ \\
\hline Free radical scavenging activity (\% inhibition) & $36.95 \pm 0.70^{b}$ & $43.07 \pm 0.14^{a}$ \\
\hline Iron $(\mathrm{mg})$ & $3.59 \pm .32^{b}$ & $4.03 \pm 0.02^{a}$ \\
\hline
\end{tabular}

The values are presented as Mean \pm Standard deviation

The values represented with different superscripts differ significantly at $\mathrm{p}<0.05$

Table 2: Sensory attributes of the blended juice as affected by different constituents

\begin{tabular}{lcccccccccc}
\hline Run & $\begin{array}{c}\text { Spinach } \\
\text { juice (\%) }\end{array}$ & $\begin{array}{c}\text { Pomegranate } \\
\text { juice (\%) }\end{array}$ & $\begin{array}{c}\text { Sugar } \\
(\%)\end{array}$ & $\begin{array}{c}\text { Pineapple } \\
(\%)\end{array}$ & $\begin{array}{c}\text { Color and } \\
\text { Appearance }(\%)\end{array}$ & $\begin{array}{c}\text { Aroma } \\
(\%)\end{array}$ & $\begin{array}{c}\text { Taste } \\
(\%)\end{array}$ & $\begin{array}{c}\text { Consistency } \\
(\%)\end{array}$ & $\begin{array}{c}\text { Mouth } \\
\text { feel }(\%)\end{array}$ & $\begin{array}{c}\text { Overall } \\
\text { acceptability }(\%)\end{array}$ \\
\hline 1 & 15 & 50 & 1 & 34 & 8.4 & 8.4 & 7.0 & 7.7 & 7.2 & 7.4 \\
2 & 6.59 & 50 & 1 & 42.41 & 8.7 & 8.8 & 7.7 & 7.5 & 7.5 & 7.3 \\
3 & 20 & 40 & 0 & 40 & 7.6 & 7.6 & 6.1 & 7.4 & 6.1 & 6.3 \\
4 & 10 & 60 & 0 & 30 & 8.9 & 8.9 & 7.5 & 7.8 & 7.4 & 7.3 \\
5 & 23.41 & 50 & 1 & 25.59 & 7.9 & 8.1 & 6.4 & 7.9 & 6.5 & 6.6 \\
6 & 15 & 50 & 1 & 34 & 8.2 & 8.4 & 7.1 & 7.7 & 7.2 & 7.2 \\
7 & 15 & 50 & 2.68 & 32.32 & 8.3 & 8.5 & 7.3 & 7.8 & 7.4 & 7.6 \\
8 & 20 & 60 & 0 & 20 & 8.6 & 8.7 & 6.9 & 7.9 & 7.0 & 7.1 \\
9 & 10 & 40 & 0 & 50 & 8.4 & 8.6 & 6.8 & 7.1 & 6.9 & 6.4 \\
10 & 20 & 60 & 2 & 18 & 8.4 & 8.5 & 7.0 & 8.1 & 7.1 & 7.2 \\
11 & 15 & 50 & 0 & 30 & 8.3 & 8.6 & 6.8 & 7.6 & 6.8 & 6.5 \\
12 & 10 & 40 & 2 & 43 & 8.4 & 8.4 & 7.0 & 7.2 & 7.1 & 7.0 \\
13 & 15 & 33.18 & 1 & 55.82 & 7.4 & 7.5 & 6.2 & 6.9 & 6.4 & 6.4 \\
14 & 15 & 50 & 1 & 34 & 8.3 & 8.5 & 6.8 & 7.7 & 6.7 & 6.7 \\
15 & 20 & 40 & 2 & 38 & 7.6 & 7.7 & 6.4 & 7.5 & 6.5 & 6.5 \\
16 & 15 & 66.82 & 1 & 16.18 & 9.0 & 9.0 & 7.8 & 8.1 & 7.9 & 7.7 \\
17 & 15 & 50 & 1 & 34 & 8.3 & 8.4 & 7.0 & 7.7 & 7.2 & 7.1 \\
18 & 10 & 60 & 2 & 28 & 8.7 & 8.9 & 7.6 & 8.2 & 7.8 & 7.6 \\
19 & 15 & 50 & 1 & 34 & 8.4 & 8.4 & 7.0 & 7.6 & 7.1 & 7.2 \\
20 & 15 & 50 & 1 & 34 & 8.3 & 8.3 & 7.1 & 7.7 & 7.2 & 7.4 \\
\hline
\end{tabular}


SI48 | Sharma et al.

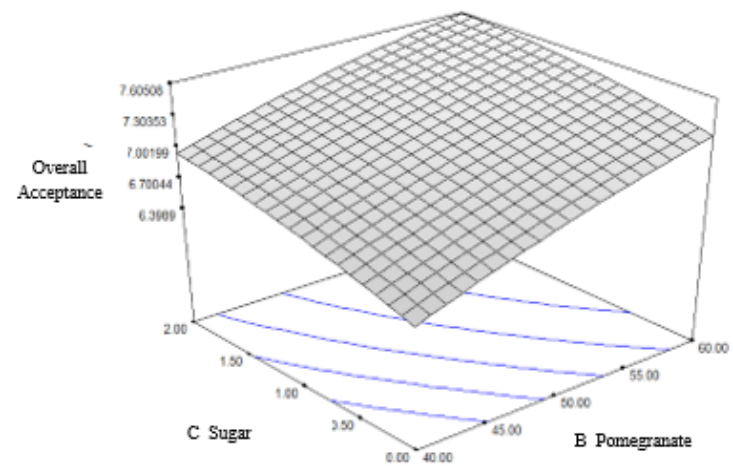

A

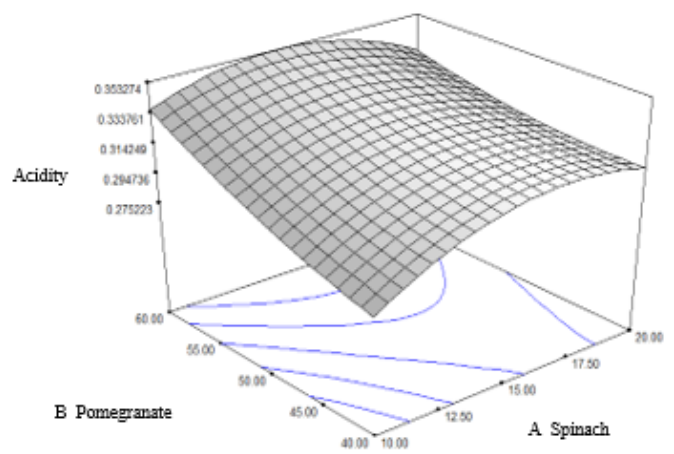

$\mathrm{C}$

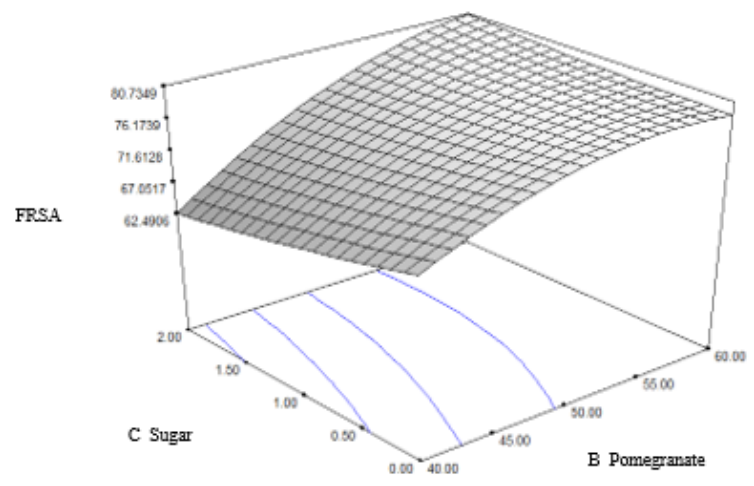

$\mathrm{E}$

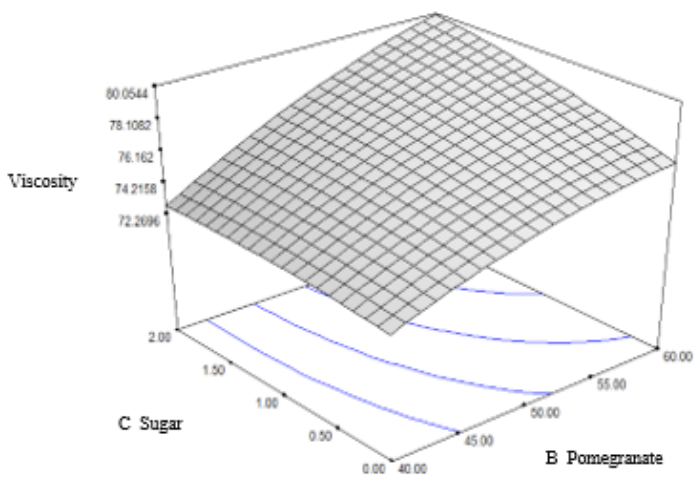

B

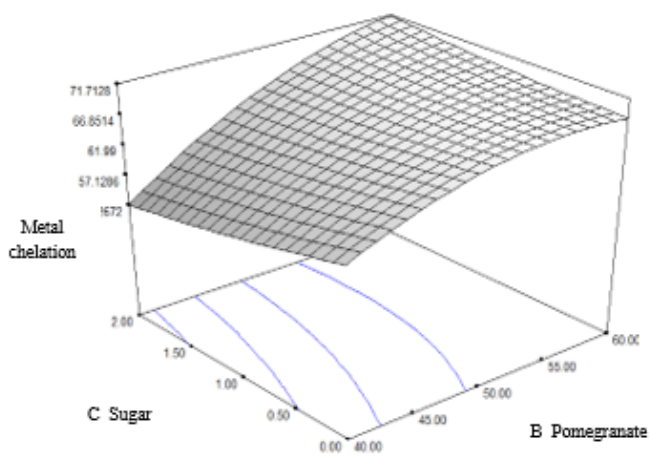

$\mathrm{D}$

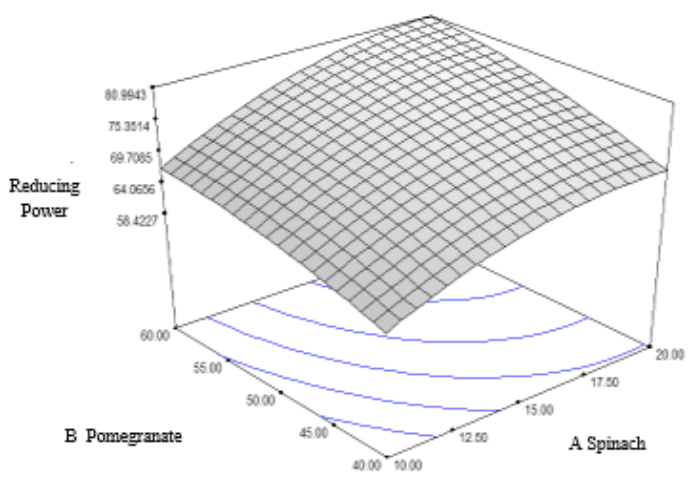

$\mathrm{F}$

Figure 1: Response surface plots for: (A) Overall acceptability, (B) Viscosity, (C) Acidity, (D) Metal chelation, (E) FRSA, (F) Reducing power 
Table 3: Physicochemical attributes of the blended juice as affected by different constituents

\begin{tabular}{|c|c|c|c|c|c|c|c|c|c|c|c|}
\hline Run & $\begin{array}{c}\text { Spinach } \\
\text { juice }(\%)\end{array}$ & $\begin{array}{c}\text { Pomegranate } \\
\text { juice }(\%)\end{array}$ & $\begin{array}{l}\text { Sugar } \\
(\%)\end{array}$ & $\begin{array}{l}\text { Pineapple } \\
\text { juice }(\%)\end{array}$ & $\begin{array}{c}\text { TSS } \\
\left({ }^{o} \text { Brix }\right)\end{array}$ & $\begin{array}{l}\text { Acidity } \\
(\%)\end{array}$ & $\begin{array}{c}\text { Metal } \\
\text { chelation (\%) }\end{array}$ & $\begin{array}{c}\text { FRSA } \\
(\%)\end{array}$ & $\begin{array}{l}\text { Reducing } \\
\text { power (\%) }\end{array}$ & $\begin{array}{l}\text { Viscosity } \\
\text { (Pa sec) }\end{array}$ & $\begin{array}{c}\text { Sedimentation } \\
(\%)\end{array}$ \\
\hline 1 & 15 & 50 & 1 & 34 & 10.03 & 0.33 & 66.12 & 75.12 & 74.12 & 76.13 & 17.05 \\
\hline 2 & 6.59 & 50 & 1 & 42.41 & 9.04 & 0.26 & 46.23 & 56.23 & 54.36 & 72.34 & 15.08 \\
\hline 3 & 20 & 40 & 0 & 40 & 11.00 & 0.31 & 64.08 & 74.08 & 71.03 & 74.73 & 17.05 \\
\hline 4 & 10 & 60 & 0 & 30 & 12.00 & 0.33 & 59.36 & 69.36 & 66.46 & 73.53 & 18.03 \\
\hline 5 & 23.41 & 50 & 1 & 25.59 & 12.08 & 0.28 & 69.12 & 79.11 & 73.98 & 78.25 & 18.05 \\
\hline 6 & 15 & 50 & 1 & 34 & 10.02 & 0.32 & 65.36 & 76.36 & 73.68 & 76.03 & 17.04 \\
\hline 7 & 15 & 50 & 2.68 & 32.32 & 11.03 & 0.33 & 65.02 & 75.02 & 75.59 & 77.34 & 17.05 \\
\hline 8 & 20 & 60 & 0 & 20 & 13.03 & 0.34 & 69.55 & 79.55 & 83.59 & 78.61 & 19.02 \\
\hline 9 & 10 & 40 & 0 & 50 & 8.02 & 0.28 & 50.47 & 60.47 & 57.39 & 69.43 & 16.03 \\
\hline 10 & 20 & 60 & 2 & 18 & 13.08 & 0.32 & 72.02 & 82.23 & 80.32 & 80.91 & 19.02 \\
\hline 11 & 15 & 50 & 0 & 30 & 10.01 & 0.33 & 70.98 & 80.98 & 75.41 & 73.64 & 17.04 \\
\hline 12 & 10 & 40 & 2 & 43 & 8.07 & 0.27 & 42.01 & 52.01 & 60.88 & 71.47 & 16.02 \\
\hline 13 & 15 & 33.18 & 1 & 55.82 & 9.06 & 0.31 & 44.59 & 54.59 & 60.27 & 69.25 & 16.04 \\
\hline 14 & 15 & 50 & 1 & 34 & 10.03 & 0.33 & 66.26 & 76.26 & 73.39 & 76.03 & 17.02 \\
\hline 15 & 20 & 40 & 2 & 38 & 11.07 & 0.31 & 57.22 & 67.22 & 70.27 & 73.42 & 17.05 \\
\hline 16 & 15 & 66.82 & 1 & 16.18 & 14.07 & 0.38 & 70.12 & 80.12 & 78.02 & 79.32 & 19.06 \\
\hline 17 & 15 & 50 & 1 & 34 & 10.03 & 0.32 & 64.15 & 74.15 & 73.39 & 76.03 & 17.03 \\
\hline 18 & 10 & 60 & 2 & 28 & 11.07 & 0.34 & 64.15 & 70.91 & 67.55 & 78.25 & 18.04 \\
\hline 19 & 15 & 50 & 1 & 34 & 10.02 & 0.33 & 67.26 & 76.53 & 73.39 & 76.45 & 17.01 \\
\hline 20 & 15 & 50 & 1 & 34 & 10.05 & 0.33 & 66.75 & 77.32 & 74.25 & 77.82 & 17.05 \\
\hline
\end{tabular}

Table 4: Coefficient estimates of sensory properties for fruit based microgreen juice

\begin{tabular}{|c|c|c|c|c|c|c|}
\hline Factors & Appearance (\%) & Aroma (\%) & Taste (\%) & Mouth feel (\%) & Consistency (\%) & Overall acceptability (\%) \\
\hline Intercepts & 8.31 & 8.40 & 7.00 & 7.10 & 7.68 & 7.17 \\
\hline $\mathrm{A}$ & $-0.26^{*}$ & $-0.25^{*}$ & $-0.34^{*}$ & $-0.31^{*}$ & $0.093^{*}$ & $-0.17^{*}$ \\
\hline B & $0.39^{*}$ & $0.38^{*}$ & $0.39^{*}$ & $0.38^{*}$ & $0.35^{*}$ & $0.38^{*}$ \\
\hline $\mathrm{C}$ & -0.29 & -0.034 & $0.11^{*}$ & $0.15^{*}$ & $0.083^{*}$ & $0.22^{*}$ \\
\hline $\mathrm{A}^{2}$ & $7.057^{*} 10^{-3}$ & 0.017 & $-8.248^{*} 10^{-3}$ & -0.055 & 0.010 & -0.094 \\
\hline $\mathrm{B}^{2}$ & -0.028 & -0.054 & -0.026 & $-2.332^{*} 10^{-3}$ & $-0.061^{*}$ & -0.059 \\
\hline $\mathrm{C}^{2}$ & $7.057^{*} 10^{-3}$ & 0.052 & $8.248^{*} 10^{-3}$ & -0.020 & $0.010^{*}$ & -0.059 \\
\hline $\mathrm{AB}$ & $0.13^{*}$ & $0.14^{*}$ & 0.013 & 0.038 & -0.075 & 0.000 \\
\hline $\mathrm{AC}$ & 0.00 & 0.013 & 0.013 & -0.012 & -0.025 & -0.075 \\
\hline $\mathrm{BC}$ & -0.050 & -0.012 & 0.037 & -0.012 & $0.050^{*}$ & -0.050 \\
\hline Model & Significant & Significant & Significant & Significant & Significant & Significant \\
\hline
\end{tabular}

A Spinach juice, B Pomegranate juice, C Sugar, $\mathrm{A}^{2}$ Quadratic terms of spinach juice, $\mathrm{B}^{2}$ Quadratic terms of pomegranate juice, $\mathrm{C}^{2}$ Quadratic terms of sugar, AB Interactive term of spinach juice and pomegranate juice, AC Interactive term of spinach juice and sugar, BC Interactive term of pomegranate juice and sugar

The values within the column of each attribute denoted with $*$ are significant at $\mathrm{p}<0.01$

IJFS | February 2021 | Volume 10 | pages SI41-SI56 
SI50 $\mid$ Sharma et al.

Table 5: Coefficient estimates of textural and antioxidant properties in fruit based microgreen juice

\begin{tabular}{lccccccc}
\hline Factors & $\begin{array}{c}\text { TSS } \\
\left({ }^{\circ} \text { Brix }\right)\end{array}$ & $\begin{array}{c}\text { Acidity } \\
(\%)\end{array}$ & $\begin{array}{c}\text { Metal } \\
\text { chelation }(\%)\end{array}$ & $\begin{array}{c}\text { FRSA } \\
(\%)\end{array}$ & $\begin{array}{c}\text { Viscosity } \\
(\text { Pa sec })\end{array}$ & $\begin{array}{c}\text { Reducing } \\
\text { power }(\%)\end{array}$ & $\begin{array}{c}\text { Sedimentation } \\
(\%)\end{array}$ \\
\hline Intercepts & 10.30 & 0.33 & 66.01 & 76.00 & 76.41 & 73.69 & 17.32 \\
$\mathrm{~A}$ & $1.09^{*}$ & $6.856^{*} 10^{-3 *}$ & $6.25^{*}$ & $6.50^{*}$ & $1.83^{*}$ & $6.29^{*}$ & $0.64^{*}$ \\
$\mathrm{~B}$ & $1.45^{*}$ & $0.020^{*}$ & $6.90^{*}$ & $6.68^{*}$ & $2.87^{*}$ & $4.99^{*}$ & $0.95^{*}$ \\
$\mathrm{C}$ & $0.25^{*}$ & $-1.464^{*} 10^{-3}$ & $-1.32^{*}$ & $-1.55^{*}$ & $1.02^{*}$ & 0.062 & 0.012 \\
$\mathrm{~A}^{2}$ & $0.27^{*}$ & $-0.020^{*}$ & $-3.12^{*}$ & $-3.19^{*}$ & $-0.37^{*}$ & $-3.30^{*}$ & $-5.830^{*} 10^{-3 *}$ \\
$\mathrm{~B}^{2}$ & $0.64^{*}$ & $6.104^{*} 10^{-3 *}$ & $-3.23^{*}$ & $-3.30^{*}$ & $-0.73^{*}$ & $-1.54^{*}$ & 0.29 \\
$\mathrm{C}^{2}$ & $0.12^{*}$ & $8.003^{*} 10^{-3}$ & 0.53 & 0.46 & -0.30 & $0.70^{*}$ & 0.10 \\
$\mathrm{AB}$ & $-0.30^{*}$ & $-1.000^{*} 10^{-2 *}$ & $-1.34^{*}$ & -0.91 & 0.061 & $0.86^{*}$ & -0.10 \\
$\mathrm{AC}$ & 0.12 & $-2.500^{*} 10^{-3}$ & -0.090 & 0.34 & $-0.72^{*}$ & $-1.08^{*}$ & 0.000 \\
$\mathrm{BC}$ & -0.13 & 0.000 & $2.82^{*}$ & $2.44^{*}$ & $0.79^{*}$ & $-0.61^{*}$ & 0.025 \\
Model & Significant & Significant & Significant & Significant & Significant & Significant & Significant \\
\hline A Sp
\end{tabular}

A Spinach juice, B Pomegranate juice, C Sugar, $\mathrm{A}^{2}$ Quadratic terms of spinach juice, $\mathrm{B}^{2}$ Quadratic terms of pomegranate juice, $\mathrm{C}^{2}$ Quadratic terms of sugar, $\mathrm{AB}$ Interactive term of spinach juice and pomegranate juice, $\mathrm{AC}$ Interactive term of spinach juice and sugar, $\mathrm{BC}$ Interactive term of pomegranate juice and sugar The values within the column of each attribute denoted with * are significant at $\mathrm{p}<0.01$

tin concentration. The viscosity is determined by the pectin colloidal content. As the fruit matures, the proto-pectin in the central lamina is converted to hydrocolloids which are soluble and easily disperse through the juice thus increasing the viscosity as shown by Wojdylo, Teleszko and Oszmianski (2014). Gabsi, Trigui, Barrington, Helal and Taherian (2013) reported that the viscosity also increases with an increase in the amount of sugar.

\section{Acidity}

As shown in Fig. 1C, the acidity of the juice blend increases as the pomegranate increases and had a significant $(\mathrm{p}<0.01)$ positive effect. This might be due to the acidic nature of pomegranate. On the other hand, spinach is basic in nature and thus the acidity decreases as the concentration of spinach microgreen increases (Table 3). Sugar has no significant effect on acidity. Therefore, the interactive effect of pomegranate and spinach microgreen is negative in the case of acidity. It is reported by Kamol, Howlader, Dhar and Aklimuzzaman (2014) that the acidity is directly dependent on the maturity of fruit. The premature fruit has maximum acidity while mature fruit has minimum acidity. It was claimed that acidity increases due to the conversion of pectic acid into pectinic acid, which decreases the $\mathrm{pH}$ of the juice blend (Wisal et al., 2013). It was shown by Rodbotten et al. (2009) that an increase in acidity decreases the consumer acceptance of juices.

\section{Antioxidant activity: reducing power, FRSA and metal chelation}

Table 3 depicts the different antioxidant activities of the juice blend. Pomegranate had a positive significant $(\mathrm{p}<0.01)$ effect on metal chelation (Fig 1D), FRSA (Fig. 1E) and reducing power (Fig. 1F) of the juice blend (Table 5). In the case of spinach, as it increases, the metal chelation, FRSA and reducing power also increases. Sugar had no significant effect on these properties of the juice blend. The increase in antioxidant activity might be due to the presence of a high amount of antioxidants in the microgreen based juice blend. It is reported by Raghavendra, Araveeti, Raghuveer Yadav, Sudharshan Raju and Siva Kumar (2013) that the reductones present in vegetables exert antioxidant action by breaking the free radical chain or by donating a hydrogen atom. It is reported by Viuda-Martos et al. (2011) that pomegranate contains certain types of compounds such as punicalagin isomers, ellegic acid derivatives and anthocyanin which 
Table 6: Optimization of microgreen based blend

\begin{tabular}{lcc}
\hline Experiments & Predicted values & Experimental values \\
\hline Color and Appearance (\%) & $8.49^{a}$ & $7.7 \pm 0.20^{b}$ \\
Aroma (\%) & $8.57^{a}$ & $7.6 \pm 0.15^{b}$ \\
Taste (\%) & $7.01^{a}$ & $6.9 \pm 0.25^{b}$ \\
Consistency (\%) & $7.92^{a}$ & $8.0 \pm 0.08^{a}$ \\
Mouth feel (\%) & $7.23^{b}$ & $7.6 \pm 0.25^{a}$ \\
Over all acceptability (\%) & $7.31^{b}$ & $7.6 \pm 0.28^{a}$ \\
TSS ( ${ }^{o}$ Brix) & $12.10^{a}$ & $11.6 \pm 0.57^{a}$ \\
Acidity (\%) & $0.33^{a}$ & $0.35 \pm 0.02^{a}$ \\
Metal chelation (\%) & $71.44^{a}$ & $72.0 \pm 0.57^{a}$ \\
FRSA (\%) & $81.07^{b}$ & $82.0 \pm 0.28^{a}$ \\
Reducing power (\%) & $78.88^{a}$ & $79.0 \pm 0.33^{a}$ \\
Viscosity (Pa sec) & $78.86^{a}$ & $76.7 \pm 0.41^{b}$ \\
Sedimentation (\%) & $18.40^{a}$ & $18.3 \pm 0.57^{a}$ \\
\hline
\end{tabular}

The experimental values are presented as Mean \pm Standard deviation The values represented with different superscripts differ significantly at $\mathrm{p}<0.05$

Table 7: Nutritional composition of fruits and spinach microgreen juice

\begin{tabular}{|c|c|c|c|c|}
\hline Nutrients & Spinach Microgreen & Pineapple & Pomegranate & Microgreen blend \\
\hline Protein $(\%)$ & $2.45 \pm 0.06^{b}$ & $0.45 \pm 0.04^{d}$ & $1.86 \pm 0.16^{c}$ & $3.62 \pm 0.18^{a}$ \\
\hline Moisture (\%) & $94.2 \pm 0.20^{a}$ & $83.6 \pm 0.05^{c}$ & $86.1 \pm 0.05^{b}$ & $80.05 \pm 0.09^{d}$ \\
\hline Ash $(\%)$ & $1.13 \pm 0.03^{a}$ & $0.86 \pm 0.09^{c}$ & $0.46 \pm 0.07^{d}$ & $1.02 \pm 0.05^{b}$ \\
\hline Potassium (mg) & $161.0 \pm 0.03^{b}$ & $99.2 \pm 0.32^{d}$ & $180 \pm 0.08^{a}$ & $156.03 \pm 3.0^{c}$ \\
\hline Sodium (mg) & $78.02 \pm 0.03^{a}$ & $5.06 \pm 0.12^{c}$ & $4.0 \pm 0.32^{d}$ & $37.0 \pm 1.0^{b}$ \\
\hline Total phenols $\left(\mathrm{GAE} \mathrm{g}^{-1}\right)$ & $0.95 \pm 0.06^{d}$ & $6.45 \pm 0.35^{a}$ & $3.34 \pm 0.11^{c}$ & $5.07 \pm 0.01^{b}$ \\
\hline Total carotenoids $\left(\mu \mathrm{g} 100 \mathrm{~g}^{-1}\right)$ & $15.08 \pm 0.05^{a}$ & $13.04 \pm 0.16^{b}$ & $8.5 \pm 0.22^{d}$ & $11.38 \pm 0.53^{c}$ \\
\hline Vitamin C (mg) & $11.8 \pm 0.0080^{c}$ & $25.0 \pm 0.23^{a}$ & $11.3 \pm 0.14^{d}$ & $21.30 \pm 0.79^{b}$ \\
\hline Reducing Power (\%) & $48.86 \pm 0.15^{c}$ & $39.0 \pm 0.25^{d}$ & $59.4 \pm 0.26^{b}$ & $76.33 \pm 4.40^{a}$ \\
\hline Metal chelation activity (\% inhibition) & $39.59 \pm 0.36^{c}$ & $22.5 \pm 0.42^{d}$ & $47.1 \pm 0.52^{b}$ & $72.07 \pm 0.57^{a}$ \\
\hline Free radical scavenging activity (\% inhibition) & $43.07 \pm 0.14^{c}$ & $40.17 \pm 0.09^{d}$ & $62.3 \pm 0.45^{b}$ & $82.01 \pm 0.28^{a}$ \\
\hline Iron (mg) & $4.03 \pm 0.02^{a}$ & $0.22 \pm 0.05^{d}$ & $0.60 \pm 0.13^{c}$ & $3.10 \pm 0.04^{b}$ \\
\hline
\end{tabular}

The values are presented as Mean \pm Standard deviation

The values represented with different superscripts differ significantly at $\mathrm{p}<0.05$ 
have the potential to scavenge free radicals and inhibit lipid oxidation. Baby spinach contains most of the flavonoids, carotenoids, vitamin $\mathrm{C}$, vitamin $\mathrm{E}$ and $\beta$-carotene which possess antioxidant benefits and acts as anti-inflammatory agents (Nemadodzi, 2015). It has been reported by Arfan et al. (2013) that the spinach leaves have para-coumaric acid derivatives which possess strong antioxidant activity.

\subsection{Optimization of microgreen based blend}

Based on the sensory scores of the juice blend, rheological properties and antioxidant properties, the optimum formulation for the development of the microgreen based blend was selected using RSM. The optimized formulation was selected as $17.26 \mathrm{~mL} 100 \mathrm{~mL}^{-1}$ spinach microgreen juice, $57.07 \mathrm{~mL} 100 \mathrm{~mL}^{-1}$ pomegranate

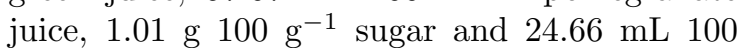
$\mathrm{mL}^{-1}$ pineapple juice. The predicted and experimental values for the optimized product are shown in Table 6. The obtained experimental values showed little difference with the predictions. The use of spinach microgreen and pineapple that contains the anti-inflammatory potential was kept as the highest priority, with highest weights. The desirability of the selected formulation is 0.821 .

\subsection{Nutritional composition of microgreen based beverage}

The nutritional composition of the optimized microgreen based beverage is shown in Table 7 . The nutritional composition of spinach microgreen is higher than the nutritional value of mature spinach. This is because the microgreens contain high amounts of bioactive compounds like vitamins, minerals and antioxidants as compared to mature greens Kou et al. (2013). The amount of total carotenoids and ascorbic acid found in the microgreens were in accordance with the values obtained by Bergquist (2006). The values of all the nutrients present in pomegranate and pineapple were found to be in accordance with the values obtained by Viuda-Martos et al. (2011), Kumar et al. (2016) and Debnath et al. (2012).
The moisture content of the microgreen blend was found to be less than the individual values of spinach microgreen, pineapple and pomegranate. At the same time, the values of different properties such as reducing power, metal chelation activity and free radical scavenging activity were found to be higher in the blend as compared to the ones found for spinach microgreen, pineapple and pomegranate. The values obtained for total phenols, carotenoids and vitamin $\mathrm{C}$ were also higher which could be beneficial for reducing inflammations and have a potent role in dealing with oxidative stress due to free radical damage (Janovská et al., 2010). According to the study conducted by Xiao et al. (2014), microgreens contain high concentrations of phytonutrients like carotenoids and vitamin C. It was reported by Leahu, Damian, Carpiuc, Oroian and Avramiuc (2013) that vitamin C content decreases with the maturation of fruit thus it is highest at the beginning of ripening and minimum at full maturity. The polyphenol content increases with fruit maturation. It was also shown by Lawless et al. (2012) that blending three juices enhances nutraceutical properties and also consumer acceptance of the blend.

\section{Conclusions}

Response surface methodology was used to optimize a microgreen and fruit based beverage. Spinach microgreen was compared to its mature counterpart and found to have a better nutritional and phytochemical profile, and thus was selected to prepare the beverage. The optimum conditions for preparation of the microgreen and fruit based beverage on a sensory and physicochemical basis were $17.26 \mathrm{~mL} 100$ $\mathrm{mL}^{-1}$ spinach microgreen juice, $57.07 \mathrm{~mL} 100$

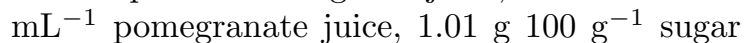
and $24.66 \mathrm{~mL} 100 \mathrm{~mL}^{-1}$ pineapple juice. The optimized beverage had overall better physicochemical properties as compared to fruits (pineapple and pomegranate) and spinach microgreen juice alone. 


\section{References}

Abedi, F., Sani, A. M. \& Karazhiyan, H. (2014). Effect of some hydrocolloids blend on viscosity and sensory properties of raspberry juice-milk. Journal of Food Science and Technology-mysore, 51(9), 2246-2250. doi:10.1007/s13197-012-0705-0

Achikanu, C. E., Eze-Steven, P. E., Ude, C. M. \& Ugwuokolie, O. C. (2013). Determination of the vitamin and mineral composition of common leafy vegetables in south eastern nigeria. Int J Curr Microbiol Appl Sci, 2(11), 347-353.

Akusu, O. M., Kiin-Kabari, D. B. \& Ebere, C. O. (2016). Quality characteristics of orange/pineapple fruit juice blends. American Journal of Food Science and Technology, 4(2), 43-47.

Anahita, A., Asmah, R. \& Fauziah, O. (2015). Evaluation of total phenolic content, total antioxidant activity, and antioxidant vitamin composition of pomegranate seed and juice. International Food Research Journal, 22(3), 1212-1217.

AOAC. (2000). The official methods of analysis of the aoac international, 18thed, washington.

Arfan, M., Gul, S., Usman, R., Khan, A., Rauf, A., Muhammad, N., ... Ali, M. (2013). The comparative free radical scavenging effect of trigonella foenumgraecum, solanum nigram and spinacia oleracea. Academic Journal of Plant Sciences, 6, 113-116. doi:10.5829/idosi.ajps.2013.6.3.1103

Bergquist, S. (2006). Bioactive compounds in baby spinach (spinacia oleracea l.)

Bhowmik, D., Gopinath, H., Kumar, B. P. \& Kumar, K. (2013). Medicinal uses of punica granatum and its health benefits. Journal of Pharmacognosy and Phytochemistry, $1(5)$.

Clark, H. R. (1995). The cure for all diseases. New Century Press.

da Silva, D. I. S., Nogueira, G. D. R., Duzzioni, A. G. \& Barrozo, M. A. S. (2013). Changes of antioxidant constituents in pineapple (ananas comosus) residue during drying process. Industrial Crops and Products, 50, 557-562. doi:10.1016/j.indcrop.2013.08.001
Debnath, P., Dey, P., Chanda, A. \& Bhakta, T. (2012). A survey on pineapple and its medicinal value. Scholars Academic Journal of Pharmacy, 1(1), 24-29.

Di Gioia, F., Bellis, P., Mininni, C., Santamaria, P. \& Serio, F. (2017). Physicochemical, agronomical and microbiological evaluation of alternative growing media for the production of rapini (brassica rapa l.) microgreens. Journal of the Science of Food and Agriculture, 97(4), 1212-1219. doi:10. $1002 /$ jsfa. 7852

Ding, P. \& Syazwani, S. (2016). Physicochemical quality, antioxidant compounds and activity of md-2 pineapple fruit at five ripening stages. International Food Research Journal, 23(2), 549-555.

Endrizzi, I., Gasperi, F., Rodbotten, M. \& Naes, T. (2014). Interpretation, validation and segmentation of preference mapping models. Food Quality and Preference, 32(100), 198-209. doi:10.1016/j.foodqual.2013.10. 002

Fawole, O. \& Opara, U. (2013). Seasonal variation in chemical composition, aroma volatiles and antioxidant capacity of pomegranate during fruit development. African Journal of Biotechnology, 12, 4006-4019. doi:10.5897/AJB2013.12337

Gabsi, K., Trigui, M., Barrington, S., Helal, A. N. \& Taherian, A. R. (2013). Evaluation of rheological properties of date syrup. Journal of Food Engineering, 117(1), 165172. doi:10.1016/j.jfoodeng.2013.02.017

Gaikwad, P. S., Shete, R. V. \& Otari, K. V. (2010). Spinacia oleracea linn: A pharmacognostic and pharmacological overview. International Journal of Research in Ayurveda and Pharmacy (IJRAP), 1(1), 7884.

Goh, S. G., Mohd Adzahan, N., Leong, C. M., Sew, C. C. \& Sobhi, B. (2012). Effect of thermal and ultraviolet treatments on the stability of antioxidant compounds in single strength pineapple juice throughout refrigerated storage. International Food Research Journal, 19, 1131-1136.

Jan, A. \& Dorcus Masih, E. (2012). Development and quality evaluation of pineapple juice 
blend with carrot and orange juice. 2, 12250 .

Janovská, D., Stocková, L. \& Stehno, Z. (2010). Evaluation of buckwheat sprouts as microgreens. Acta Agriculturae Slovenica, 95 (2), 157.

Jenitha, A. X. \& Anusuya, A. (2016). Phytochemical screening and in vitro antioxidant activity of ananas comosus. $J$ Research Pharma Pharmacotherap, 5(2), 162-169.

Kamol, S. I., Howlader, J., Dhar, G. C. S. \& Aklimuzzaman, M. (2014). Effect of different stages of maturity and postharvest treatments on quality and storability of pineapple. Journal of the Bangladesh Agricultural University, 12(2), 251-260.

Kamtekar, S., Keer, V. \& Patil, V. (2014). Estimation of phenolic content, flavonoid content, antioxidant and alpha amylase inhibitory activity of marketed polyherbal formulation. Journal of applied pharmaceutical Science, 4(9), 61.

Kar, F. \& Kaya, B. A. (2014). The rheological behavior of concentrated orange juice. International Conference on Heat Transfer, Fluid Mechanics and Thermodynamics.

Kou, L., Luo, Y., Yang, T., Xiao, Z., Turner, E. R., Lester, G. E., ... Camp, M. J. (2013). Postharvest biology, quality and shelf life of buckwheat microgreens. $L W T$ Food Science and Technology, 51(1), 73-78. doi:10.1016/j.lwt.2012.11.017

Kumar, K., Chandra, S., Kumar, V. \& Prince. (2016). Medico-nutritional importance and value added products of pineapple - A Review. South Asian J. Food Technol, 2(1), 290-298.

Landon, S. (2007). Fruit juice nutrition and health. Food Australia, 59(11), 533-538.

Lawless, L. J. R., Threlfall, R. T., Howard, L. R. \& Meullenet, J.-F. (2012). Sensory, compositional, and color properties of nutraceutical-rich juice blends. American Journal of Enology and Viticulture, 63(4), 529-537. doi:10.5344/ajev.2012.11125

Leahu, A., Damian, C., Carpiuc, N., Oroian, M. \& Avramiuc, M. (2013). Change in colour and physicochemical quality of carrot juice mixed with other fruits. Journal of Agroali- mentary processes and technologies, 19(2), 241-246.

Lugwisha, E. (2014). Determination of physicochemical properties of pomegranate (punica granatum l.) fruits of dar es salaam tanzania. Journal of Food and Nutrition Sciences, 2, 277. doi:10.11648/j.jfns.20140206. 16

Mehta, D. \& Belemkar, S. (2014). Pharmacological activity of spinacia oleracea linn. 2.

Mir, S. A., Shah, M. A. \& Mir, M. M. (2017). Microgreens: Production, shelf life, and bioactive components. Critical Reviews in Food Science and Nutrition, 57(12), 27302736. doi:10.1080/10408398.2016.1144557

Mohan, S. C., Balamurugan, V., Elayaraja, R. \& Prabakaran, A. S. (2012). Antioxidant and phytochemical potential of medicinal plant kalanchoe pinnata. International Journal of Pharmaceutical Sciences and Research, 3(3), 881 .

Mohideen, F. W., Solval, K. M., Li, J., Zhang, J., Chouljenko, A., Chotiko, A., ... Sathivel, S. (2015). Effect of continuous ultra-sonication on microbial counts and physico-chemical properties of blueberry (vaccinium corymbosum) juice. LWT-Food Science and Technology, 60(1), 563-570. doi:10.1016/j.lwt.2014.07.047

Nemadodzi, L. E. (2015). Growth and development of baby spinach (spinacia oleracea l.) with reference to mineral nutrition (Doctoral dissertation, University of South Africa, Pretoria). Retrieved from http:// hdl.handle.net/10500/18673

Oyeleke, O. (2013). Development and analysis of blended pineapple-watermelon ready to drink (rtd) juice. IOSR Journal Of Environmental Science, Toxicology And Food Technology, 4, 22-24. doi:10.9790/24020462224

Pimentel, T. C., Madrona, G. S. \& Prudencio, S. H. (2015). Probiotic clarified apple juice with oligofructose or sucralose as sugar substitutes: Sensory profile and acceptability. LWT-Food Science and Technology, 62(1, 2, SI), 838-846. doi:10.1016/j.lwt. 2014.08.001

Pinto, E., Almeida, A. A., Aguiar, A. A. \& Ferreira, I. M. P. L. V. O. (2015). Compar- 
ison between the mineral profile and nitrate content of microgreens and mature lettuces. Journal of Food Composition and Analysis, 37, 38-43. doi:10.1016/j.jfca . 2014.06.018

Raghavendra, M., Araveeti, M. R., Raghuveer Yadav, P., Sudharshan Raju, A. \& Siva Kumar, L. (2013). Comparative studies on the in vitro antioxidant properties of methanolic leafy extracts from six edible leafy vegetables of india. Asian Journal of Pharmaceutical and Clinical Research, 6, 96-99.

Rangana, S. (1997). Hand book of analysis and quality control of fruits and vegetables products, tata mcgrow hill publ. Co., Ltd., New Delhi, 88-89.

Rao, K. N. V., Tabassum, B., Babu, S. R., Raja, A. \& Banji, D. (2015). Preliminary phytochemical screening of spinacia oleracea 1. World Journal of Pharmacy and Pharmaceutical Sciences, 4(6), 532-551.

Reboucas, M. C., Rodrigues, M. d. C. P., de Freitas, S. M. \& Ferreira, B. B. A. (2016). The physicochemical optimization and acceptability of a cashew nut-based beverage varying in mango juice and sugar: A pilot study. Beverages, 2(3). doi:10.3390/ beverages 2030023

Rekha, C., Poornima, G., Manasa, M., Abhipsa, V., Pavithra Devi, J., T. Vijay Kumar, H. \& Prashith, T. R. (2012). Ascorbic acid, total phenol content and antioxidant activity of fresh juices of four ripe and unripe citrus fruits. Chemical Science Transactions, 1, 303-310. doi:10.7598/ cst2012. 182

Rodbotten, M., Martinsen, B. K., Borge, G. I., Mortvedt, H. S., Knutsen, S. H., Lea, P. \& Naes, T. (2009). A cross-cultural study of preference for apple juice with different sugar and acid contents. Food Quality and Preference, 20(3), 277-284. doi:10.1016/j. foodqual.2008.11.002

Romelle, F. D., Rani, P. A. \& Manohar, R. S. (2016). Chemical composition of some selected fruit peels. European Journal of Food Science and Technology, 4(4), 12-21.

Shiban, M. S., Al-Otaibi, M. M. \& Al-Zoreky, N. S. (2012). Antioxidant activity of pomegranate (punica granatum l.) fruit peels. Food and Nutrition Sciences, 3(07), 991.

Sun, J., Xiao, Z., Lin, L.-z., Lester, G. E., Wang, Q., Harnly, J. M. \& Chen, P. (2013). Profiling polyphenols in five brassica species microgreens by uhplc-pda-esi/hrmsn. Journal of Agricultural and Food Chemistry, 61(46), 10960-10970. doi:10.1021/ jf401802n

Viuda-Martos, M., Ruiz-Navajas, Y., FernandezLopez, J., Sendra, E., Sayas-Barbera, E. \& Perez-Alvarez, J. A. (2011). Antioxidant properties of pomegranate (punica granatum 1.) bagasses obtained as co-product in the juice extraction. Food Research International, 44(5), 1217-1223. doi:10.1016/j.foodres.2010.10.057

Weber, C. F. (2017). Broccoli microgreens: A mineral-rich crop that can diversify food systems. Frontiers in Nutrition, 4. doi:10. 3389/fnut.2017.00007

Wisal, S., Ullah, J., Zeb, A. \& Khan, M. Z. (2013). Effect of refrigeration temperature, sugar concentrations and different chemicals preservatives on the storage stability of strawberry juice. International Journal of Engineering and Technology, 13(02), 160168.

Wojdylo, A., Teleszko, M. \& Oszmianski, J. (2014). Physicochemical characterisation of quince fruits for industrial use: Yield, turbidity, viscosity and colour properties of juices. International Journal of Food Science and Technology, 49(8), 1818-1824. doi:10.1111/ijfs.12490

Xiao, Z., Codling, E. E., Luo, Y., Nou, X., Lester, G. E. \& Wang, Q. (2016). Microgreens of brassicaceae: Mineral composition and content of 30 varieties. Journal of Food Composition and Analysis, 49, 87-93. doi:10. 1016/j.jfca.2016.04.006

Xiao, Z., Lester, G. E., Luo, Y. \& Wang, Q. (2012). Assessment of vitamin and carotenoid concentrations of emerging food products: Edible microgreens. Journal of Agricultural and Food Chemistry, 60(31), 7644-7651. doi:10.1021/jf300459b

Xiao, Z., Luo, Y., Lester, G. E., Kou, L., Yang, T. \& Wang, Q. (2014). Postharvest quality and shelf life of radish microgreens as im- 
SI56 | Sharma et al.

pacted by storage temperature, packaging film, and chlorine wash treatment. $L W T$ Food Science and Technology, 55(2), 551558. doi:10.1016/j.lwt.2013.09.009

Yadav, R. K., Kalia, P., Kumar, R. \& Jain, V. (2013). Antioxidant and nutritional activity studies of green leafy vegetables. Int $J$ Agric Food Sci Tech, 4, 707-12. 